\title{
The Wnt Pathway Target Gene CCND1 Changes Mitochondrial Localization and Decreases Mitochondrial Activity in Colorectal Cancer Cell Line SW480
}

\author{
Annica Vlad-Fiegen1, Natalie Veronika Freytag', , Susanne Dorn³, Oliver Müller, Sonja Eberth ${ }^{2 *}$ \\ ${ }^{1}$ DLR Project Management Agency, German Aerospace Center, Bonn, Germany \\ ${ }^{2}$ Molecular Cancer Research, Leibniz Institute DMSZ, Braunschweig, Germany \\ ${ }^{3}$ Leibniz Research Centre for Working Environment and Human Factors, Dortmund, Germany \\ ${ }^{4}$ University of Applied Sciences Kaiserslautern, Zweibrücken, Germany \\ Email: ${ }^{*}$ sonja.eberth@dsmz.de
}

How to cite this paper: Vlad-Fiegen, A., Freytag, N.V., Dorn, S., Müller, O. and Eberth, S. (2016) The Wnt Pathway Target Gene $C C N D 1$ Changes Mitochondrial Localization and Decreases Mitochondrial Activity in Colorectal Cancer Cell Line SW480. Journal of Biosciences and Medicines, 4, 132-143.

http://dx.doi.org/10.4236/jbm.2016.412017

Received: September 27, 2016

Accepted: December 11, 2016

Published: December 14, 2016

Copyright $\odot 2016$ by authors and Scientific Research Publishing Inc. This work is licensed under the Creative Commons Attribution International License (CC BY 4.0).

http://creativecommons.org/licenses/by/4.0/

\section{Abstract}

Mutations leading to constitutive activation of the Wnt pathway and its target genes are frequently observed in cancer. The Wnt pathway promotes cell proliferation and increasing evidence supports its role also in cancer cell metabolism. This study aims to elucidate the role of the $\mathrm{Wnt} / \beta$-catenin target gene $C C N D 1$ in these processes in colorectal cancer. We analyzed whether knock-down of CCND1 affects cell cycle progression and energy metabolism in a colorectal cancer cell line. Down-regulation of $C C N D 1$ led to retardation of the cell cycle. The proportion of cells in the G0 phase increased, while the amount of cells in the S- and G2/M phase decreased. Interestingly, knock-down of CCND1 changed the perinuclear localization of mitochondria into a homogeneous distribution within the cytosol. In addition CCND1 knockdown led to an increase of the intracellular ATP level indicating that cyclin D1 reduced mitochondrial activity. Our findings suggest that in addition to its role in cell cycle regulation, the Wnt target gene CCND1 regulates mitochondrial localization and inhibits mitochondrial activity in colorectal cancer cells.

\section{Keywords}

ATP, Cyclin D1, Colorectal Cancer, Mitochondria, Wnt

\section{Introduction}

The Wnt pathway controls several different cellular processes and mutations in com- 
ponents of the Wnt pathway are frequently found in solid cancers [1]. Besides other features, the Wnt pathway regulates pluripotency in stem cells and cancer stem cells [2]. Key event of the canonical Wnt pathway is the regulation of the level of the free proto-oncoprotein $\beta$-catenin which is encoded by $C T N N B 1$. In a cell with an inactive Wnt pathway, the $\beta$-catenin level is kept low, whereas in the Wnt-activated cell $\beta$-catenin is stabilized, accumulates in the cytoplasm and translocates into the nucleus. Nuclear $\beta$-catenin forms a complex with transcription factors of the T-cell factor/Lymphoid enhancer factor (TCF/LEF) family, which activates transcription of many different target genes [3] [4]. A detailed list of the Wnt target genes can be found on the Wnt homepage [5].

The gene CCND1 codes for the cyclin dependent kinase (cdk) activator cyclin D1. CCND1 has been described as a Wnt target gene in different systems, e.g. human colorectal cancer cells [6] [7] and human teratocarcinoma cells [8]. However, these results could not be confirmed in other studies [9] [10] [11]. Nevertheless, in cell lines CCND1 can be activated upon extracellular stimulation of the canonical Wnt pathway and belongs to the early target genes [12]. In complex with cdk4 or cdk6 cyclin D1 activates G1/S phase transition [13] [14] [15]. In addition to its function in cell cycle progression, cyclin D1 has emerging roles in mitochondrial metabolism [16]. Wnt signalling is known to be involved in metabolic homeostasis in normal cells [17] and recent data also support a role for the Wnt pathway in cancer cell metabolism since Pate et al. reported that Wnt signalling reduces glycolytic metabolism in colon cancer cells [18]. Until now the extent to which $C C N D 1$-one of the main Wnt target genes-is able to influence mitochondrial metabolism in colorectal cancer cells has remained unknown.

Therefore, we investigated in this study the impact of cyclin D1 on cell cycle distribution and mitochondrial activity in a colorectal cancer cell line harboring a constitutive active Wnt pathway. We demonstrate here that $C C N D 1$ is one of the Wnt targets that is not only involved in proliferation, but also in metabolic reprogramming of colorectal cancer cells.

\section{Materials and Methods}

\subsection{Cell Lines and siRNA Transfection}

In the human colorectal carcinoma cell line SW480 the Wnt pathway is constitutively activated and the $\beta$-catenin level is increased due to a lack of full-length APC protein [19]. SW480 cells were obtained from the DSMZ cell line bank (Braunschweig, Germany) and were cultured at $37^{\circ} \mathrm{C}$ and $7.5 \% \mathrm{CO}_{2}$ in a humidified atmosphere in DMEM (Invitrogen, Karlsruhe, Germany) supplemented with $10 \%(\mathrm{v} / \mathrm{v})$ fetal calf serum, penicillin $(2.85 \mathrm{U} / \mathrm{ml})$ and streptomycin $(2.85 \mu \mathrm{g} / \mathrm{ml})$, L-glutamine $(11.4 \mathrm{mM})$, non-essential amino acids $(0.57 \mathrm{mM})$ and sodium pyruvate $(11 \mathrm{nM})$. siRNA was purchased from Dharmacon (distributed by Perbio, Bonn, Germany). Among these siRNAs were cyclin D1 siGENOME SMARTpool, the $\beta$-catenin siGENOME SMARTpool and GAPDH siGENOME SMARTpool. As a control siCONTROL non-targeting \#1 was used. Cells were transfected using the transfection reagent DharmaFECT 1 (Dharmacon) according 
to the manufacturer's instructions.

\subsection{Purification and Reverse Transcription of RNA}

Purification of RNA was performed using the RNeasy Mini Kit (Qiagen, Hilden, Germany) and following the supplied protocol. Reverse transcription of $1.5 \mu \mathrm{g}$ total RNA was performed in a total volume of $20 \mu \mathrm{l} 1 \times \mathrm{RT}$ buffer containing $1 \mu \mathrm{l}$ Omniscript RT (Qiagen), $1 \mu \mathrm{M}$ oligo-dT primer, $1 \mathrm{U}$ RNaseOut and $500 \mu \mathrm{M}$ dNTP by incubation for $60 \mathrm{~min}$ at $37^{\circ} \mathrm{C}$ followed by an incubation for $5 \mathrm{~min}$ at $93^{\circ} \mathrm{C}$.

\subsection{Quantitative Real-Time PCR}

Quantitative real-time PCR (qRT-PCR) was performed using QuantiTect SYBR Green PCR Kit (Qiagen) following the protocol of the manufacturer. Each reaction was done in triplicates using the GeneAmp 5700 Sequence Detection System (Applied Biosystems, Carlsbad, USA). Data were evaluated with the GeneAmp 5700 SDS software, $A C T B$ was used as endogenous control. The sequences of the primers used for qRT-PCR are for $A C T B$ 5'-gtcttcccctccatcgtgggg-3' (forward) and 5'-gtgaggatgcctctcttgctctg-3' (reverse), for CTNNB1 5'-gatcttggacttgatattggtgcccag-3' (forward) and 5'-tccatacccaaggcatcctggcc-3' (reverse), and for $C C N D 15^{\prime}$-gcctgaacctgaggagcccca-3' (forward) and 5' -gtcacacttgatcactctgg3' (reverse).

\subsection{Immunocytochemistry and Fluorescence Microscopy}

Staining of mitochondria was performed with the dye MitoTracker ${ }^{\circledast}$ Green FM from Molecular Probes (Invitrogen, Karlsruhe, Germany). Cells were cultivated on glass slides, stained with $200 \mathrm{nM}$ MitoTracker ${ }^{\oplus}$ Green FM in DMSO for 45 min at $37^{\circ} \mathrm{C}$ and fixed for $20 \mathrm{~min}$ with formaldehyde (3.7\% in PBS). Next, cells were washed with medium, permeabilized in cold acetone/methanol (1:1) for $5 \mathrm{~min}$ at $-20^{\circ} \mathrm{C}$ and air-dried for $10 \mathrm{~min}$ at room temperature. Cell nuclei were counterstained in $0.05 \mu \mathrm{g} / \mathrm{ml}$ DAPI (4,6-Diamidino-2-phenylindole) in PBS for 5 min, washed once with PBS and mounted on slides with fluorescent mounting medium (Dako, Glostrup, Denmark). Analysis and evaluation were performed with the microscope Axiophot (Zeiss, Oberkochen, Germany) and the software Axiovision Release 4.6.3.

\subsection{Flow Cytometry}

Staining of the cells with MitoTracker ${ }^{\oplus}$ Green FM was performed as described above for fluorescence microscopy. After harvesting the cells were centrifuged for $5 \mathrm{~min}$ at 1500 $\mathrm{rpm}$ and resuspended in PBS. Fixation and permeabilization of $1 \times 10^{6}$ cells were performed with commercial reagents (BD Cytofix/Cytoperm Fixation/Permeabilization Kit from Becton Dickinson, Heidelberg, Germany) by following the protocol of the manufacturer. The cells were analyzed by FACS (LSRII from BD) and data were evaluated with the software FlowJo (TreeStar Inc., Ashland, USA).

Proportion of cells in different cell cycle phases were determined by propidium iodide staining and flow cytometry. After harvesting the cells were centrifuged for $5 \mathrm{~min}$ 
at $1500 \mathrm{rpm}$ and resuspended in PBS. One million cells were resuspended in $500 \mu \mathrm{l}$ lysis buffer including $100 \mathrm{ng} / \mu \mathrm{l}$ RNase and $10 \mathrm{ng} / \mu \mathrm{l}$ propidium iodide (PI) and incubated for $1 \mathrm{~h}$ at $4^{\circ} \mathrm{C}$. Next cells were analyzed by FACS (FACS Calibur from BD) and data were evaluated with the software CellQuestPro (BD).

\subsection{Protein Gel Electrophoresis and Western Blot}

Cell lysates were electrophoresed in a vertical mini-system (BioRad, München, Germany) using standard buffers. Proteins were transferred on a PVDF membrane (GE Healthcare, München, Germany (GE)) in a semi-dry cell (Biometra, Göttingen, Germany). The membrane was blocked in 5\% milk powder in PBS/T (PBS with $0.5 \%$ Tween20). Next, the primary antibody was added at a specific dilution. Anti-cyclinD1 antibody (Santa Cruz Biotechnology, Heidelberg, Germany) was used at a 1:500 dilution, anti- $\beta$-actin (Abcam, Cambridge, UK) was used at 1:20,000. The membrane was washed in PBS/T before adding the secondary HRPO-coupled antibody (GE) at a dilution of 1:10,000. Proteins were detected by enhanced chemiluminescence (ECL) using ECL Western blotting substrate kit (Abcam, Berlin, Germany) and Hyperfilm ECL (GE).

\subsection{Analysis of Cellular ATP Level}

Total cellular ATP level was measured using CellTiter-Glo ${ }^{\circledast}$ Luminescent Cell Viability Assay (Promega, Mannheim, Germany) according to the manufacturer's instructions. Twenty-four hours prior to ATP measurements SW480 cells were transfected with siRNAs against CCND1 (CCND1_5 SI02654540, CCND1_6 SI02654547 in a molar ratio 1:1, Qiagen) and AllStars Negative Control siRNA as control (ID 1027280, Qiagen) using HiPerFect Transfection Reagent (Qiagen). In order to determine the relative amount of total ATP per cell, cells were harvested and counted by live-dead staining with trypan blue (Sigma, München, Germany) in a hemocytometer. Samples were measured in triplicates in 96-well plates using 50,000 viable cells per well against a standard curve with ATP (Roth, Karlsruhe, Germany) using CellTiter-Glo Reagent in a microplate reader (TECAN infinite M200, Tecan Group, Männedorf, Switzerland).

\section{Results}

\subsection{Cyclin D1 Is a Wnt Target Gene in SW480 Cells}

Because only a few Wnt target genes are universal across cell types [3], CCND1 had to be confirmed as $\mathrm{Wnt} / \beta$-catenin target gene in the chosen model cell line. In this study we used the colorectal cancer cell line SW480 that harbors a constitutively active canonical Wnt pathway. Therefore, we inactivated the Wnt pathway by decreasing $\beta$ catenin levels with siRNA in SW480 cells. Figure 1(a) shows the decrease of the relative $C T N N B 1$ level of more than $80 \% 24,48$ and $72 \mathrm{~h}$ after transfection. The CCND1 mRNA level in $\beta$-catenin siRNA treated SW480 cells decreased by $30 \%$ (Figure $1(\mathrm{~b})$ ). Therefore, $C C N D 1$ expression depends on $\beta$-catenin and $C C N D 1$ could be confirmed as Wnt target gene in SW480 cells. 


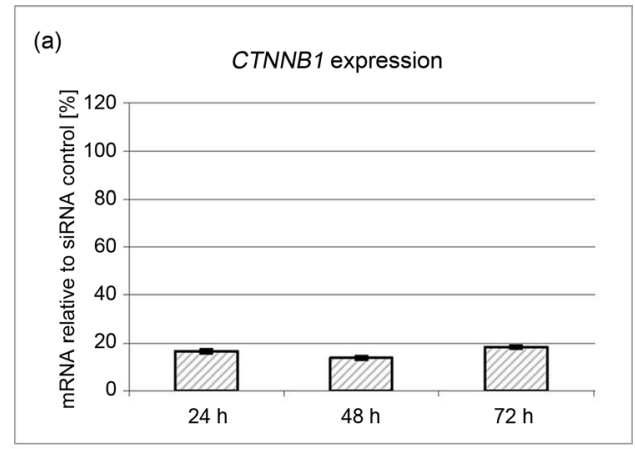

(b)

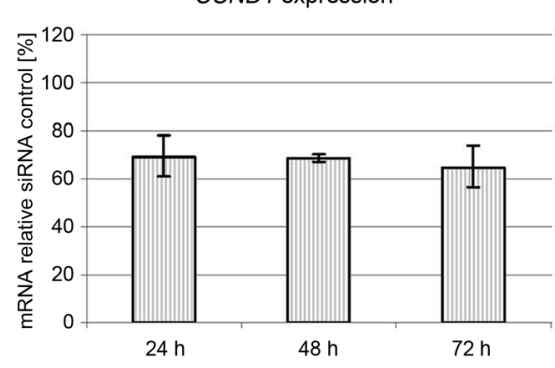

Figure 1. CCND1 expression depends on $\beta$-catenin in SW480 cells. Transfection of CTNNB1 siRNA into SW480 cells downregulates expression levels of CTNNB1 mRNA (a) and effects a reduced expression of CCND1 (b) in comparison to cells transfected with control siRNA. Expression levels were analyzed by qRT-PCR at 24, 48 and $72 \mathrm{~h}$ after transfection of CTNNB1 siRNA or control siRNA. At each time point expression level in control siRNA treated cells was set at $100 \% . \mathrm{n}=2$.

\subsection{Cyclin D1 Promotes G1/S Transition in SW480 Cells}

Next, we tested the influence of cyclin D1 on cell cycle progression. Therefore, SW480 cells were transfected with siRNA against CCND1 or a non-silencing control siRNA and knock-down was verified at the mRNA level (Figure 2(a)) and the protein level (Figure 2(b)). Analysis of the relative amounts of cells in different phases of the cell cycle was performed using propidium iodide staining and flow cytometry (Figure 2(c)). Down-regulation of $C C N D 1$ leads to an increase of the relative cell number in the G0/ G1 phase and to a decrease of the relative cell number in the $S-$ and $G_{2} / M$ phase, respectively. Thus, cyclin D1 promotes proliferation of SW480 cells.

\subsection{Cyclin D1 Alters Mitochondrial Distribution and Activity in SW480 Cells}

Mitochondrial distribution and mass was analyzed in CCND1 siRNA treated cells to determine the role of cyclin D1 in this process. The mitochondria were visualized with MitoTracker ${ }^{\circledR}$ Green FM, which specifically intercalates into the mitochondrial membrane, $48 \mathrm{~h}$ post transfection of siRNA against CCND1 or non-silencing control siRNA. Interestingly, the perinuclear mitochondrial distribution was abolished in cells upon CCND1 knock-down leading to a homogenous distribution of mitochondria within the cytosol (Figure 3(a)). In addition, flow cytometry showed that the fluorescent signal of 

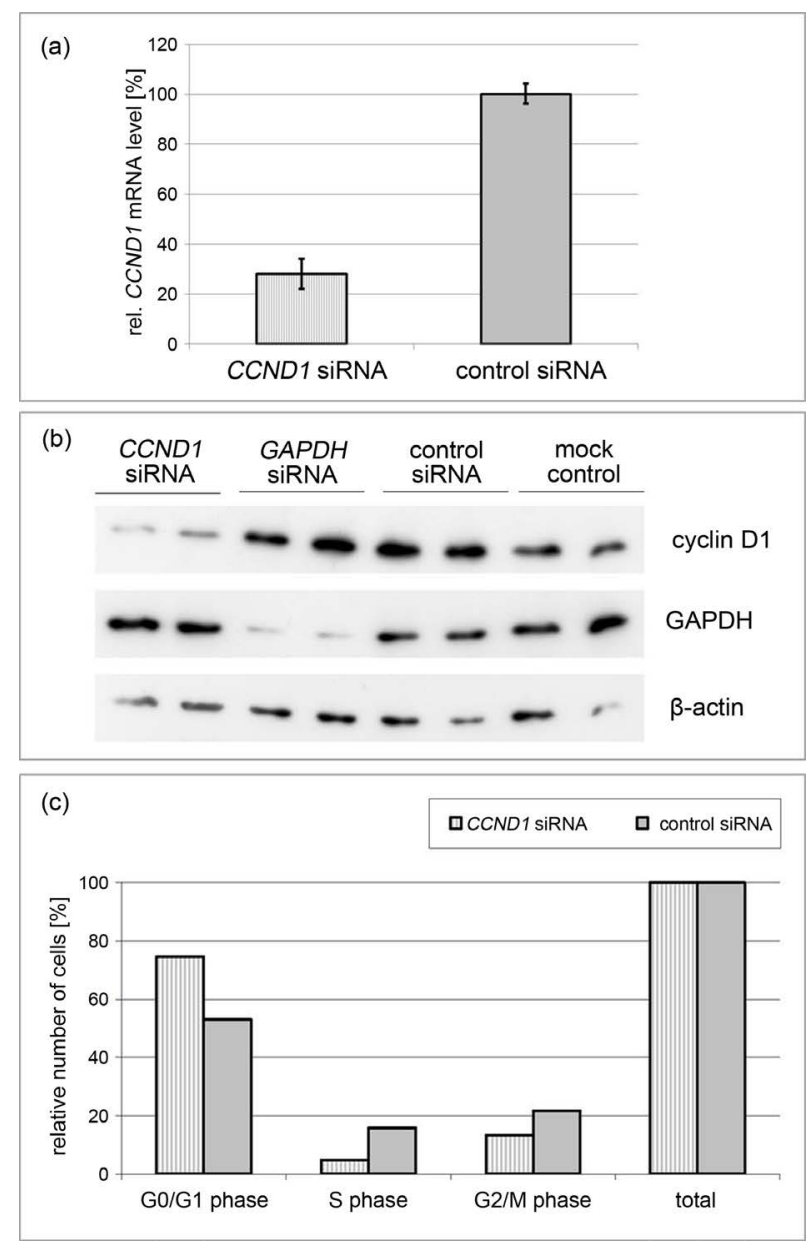

Figure 2. Knock-down of CCND1 in SW480 cells alters cell cycle distribution. (a) qRT-PCR shows relative mRNA level of $C C N D 1$ after transfection of siRNA against CCND1. The mRNA level in non-targeting siRNA treated cells was set at $100 \% . \mathrm{n}=3$. (b) Effect of CCND1 knockdown on cyclin D1 protein level as shown by a representative Western Blot $48 \mathrm{~h}$ post transfection. GAPDH siRNA transfection served as positive control. All transfections were performed in duplicates. (c) The relative amount of cells in the G0/G1-, S- and G2/M phase compared to nonsilencing control siRNA treated cells $48 \mathrm{~h}$ after transfection. $\mathrm{n}=2$.

mitochondria was increased in cells with knocked-down CCND1 when compared to control cells (Figure 3(b) and Figure 3(c)), indicating that cyclin D1 affects the mitochondrial mass in the cells.

In order to test if cyclin D1 also influences mitochondrial activity, we next investigated the intracellular ATP level. Again SW480 cells were transfected with siRNA against CCND1 or non-silencing siRNA as control, and the cellular ATP levels were determined $24 \mathrm{~h}$ post transfection with an ATP assay that is based on the luminescence released during an ATP-dependent luciferase reaction. After CCND1 knock-down the relative cellular ATP level increased 1.5 fold in comparison to the control (Figure 3(d)). Expression analysis of $C C N D 1$ in these samples confirmed that CCND1 mRNA level significantly decreased to $40 \%$ after siRNA transfection (Figure $3(\mathrm{e})$ ). Thus, cyclin D1 does not only influence the mitochondrial mass in SW480 cells, but also the mitochondrial 

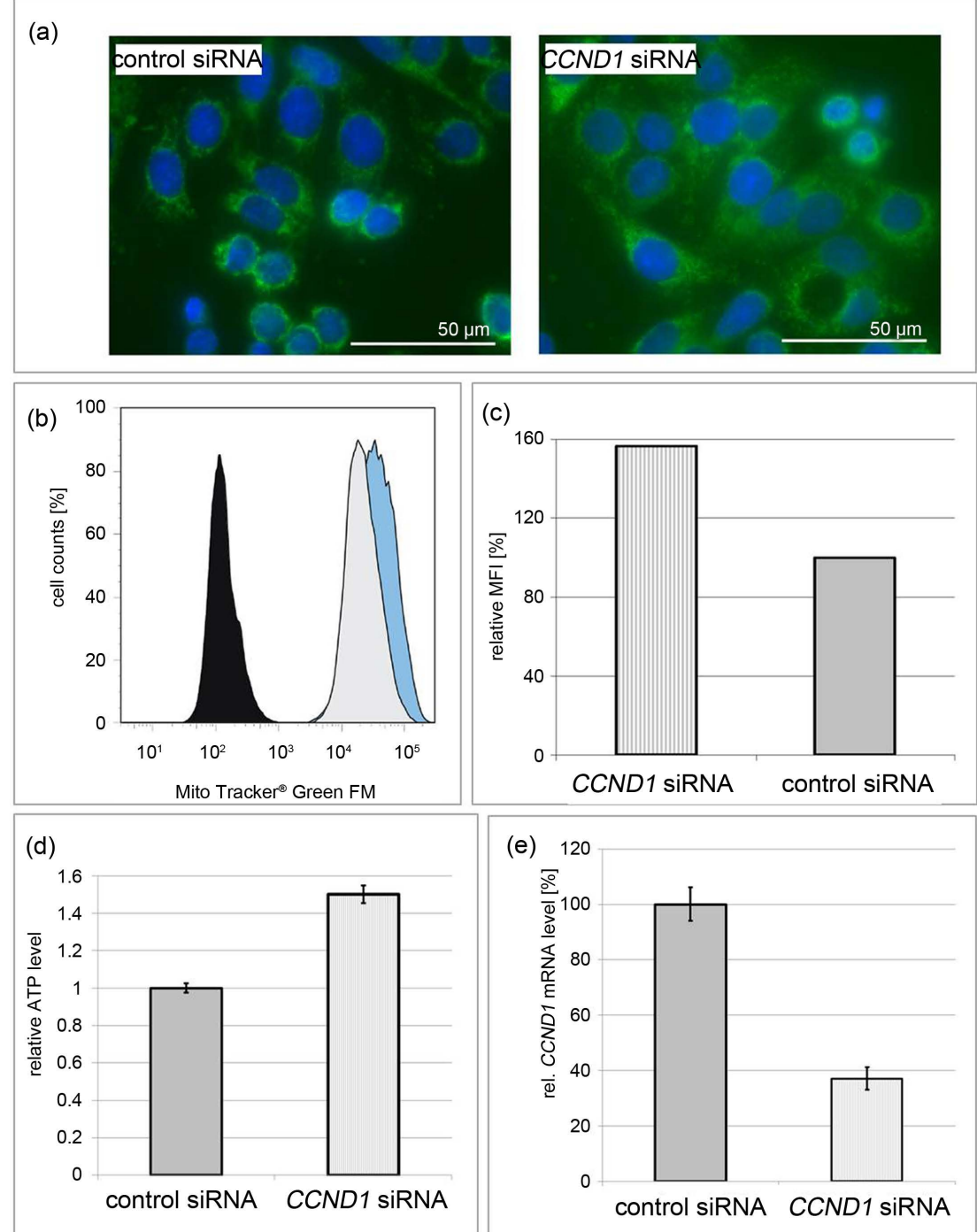

Figure 3. CCND1 regulates mitochondrial distribution and cellular ATP levels in SW480 cells. (a) Immunofluorescences of CCND1 siRNA or control siRNA treated cells after MitoTracker ${ }^{\circledast}$ Green FM (green) staining. Nuclei of SW480 cells were counterstained with DAPI (blue). (b) Flow cytometry analysis after MitoTracker ${ }^{\circledR}$ Green FM staining. Representative histograms for cells transfected with siRNA against CCND1 (blue) or non-silencing control siRNA (grey) in comparison to untreated and unstained cells (black) $48 \mathrm{~h}$ post transfection. (c) Quantification of the relative mean fluorescence intensity (MFI) of MitoTracker ${ }^{\circledast}$ Green FM as shown in (b). (d) Relative total cellular ATP levels determined $24 \mathrm{~h}$ after transfection of siRNA against CCND1 or non-targeting siRNA as control. The ATP amount in the control was set at 1 . Error bars indicate standard deviation of technical triplicates. (e) The results of the qRT-PCR show the relative mRNA level of CCND1 to control within the samples shown in (d). Shown are representative data of one of three biological replicates.

activity as verified by the increase of the cellular ATP-level after CCND1 knock-down.

\section{Discussion}

In this study, we investigated to which extent cyclin D1 as one of the major Wnt targets 
is responsible for mediating downstream effects on proliferation and metabolism of constitutively active Wnt signaling in colorectal cancer cells. In accordance with previous studies [6], we confirmed $C C N D 1$ as a canonical Wnt target gene in the colorectal cancer cell line SW480. Like most human colon cancers, this cell line has no functional APC protein, thus resulting in the accumulation of $\beta$-catenin. Knock-down of $\beta$-catenin in SW480 led to a decrease in CCND1 transcript level (Figure 1). In order to investigate the impact of the Wnt target cyclin D1 on proliferation, cell cycle progression was investigated by propidium iodide staining and flow cytometry. As expected, a cell cycle arrest in the G1 phase was observed upon knock-down of CCND1 (Figure 2). The results indicate that proliferation, specifically the G1/S transition during cell cycle progression, of SW480 cells is significantly regulated by CCND1. This conclusion is in agreement with other studies showing that cyclin D1 is important for G1/S progression [20]. In addition to its classical function in cell cycle progression, cyclin D1 is known to regulate mitochondrial metabolism [16]. For example it was shown in mice that cyclin D1 deficiency increases mitochondrial size and activity [21].

Mitochondria play an important role in different cellular processes including growth, division, energy metabolism and apoptosis [22] [23]. They are dynamic structures that merge and divide. The mitochondrial network is continuously rearranged [24]. Importantly, the mitochondrial energy production influences cellular proliferation and tumor progression. An altered energy metabolism is a hallmark of tumor cells [22]. In a normal cell, mitochondria are responsible for the production of more than $90 \%$ of the energy, predominantly by oxidative phosphorylation. In contrast, tumor cells produce a significant part of their energy by glycolysis, even under aerobic conditions. Pyruvate, the product of glycolysis, is metabolized to lactate, a process known as Warburg effect [25].

Although less ATP is produced during "aerobic glycolysis", this strategy provides a growth advantage for tumor cells [26]. Tumor cells adapt to hypoxic conditions and the fermentation of pyruvate to lactate, which leads to an acidification of the tumor microenvironment, facilitating tumor invasion [27] [28]. Consequently, the involvement of the mitochondria during tumorigenesis is not only limited to their well-known role in apoptosis, but they also have an influence on cellular proliferation and tumor progression [22].

In this study, we investigated the influence of the Wnt pathway target gene CCND1 on distribution and activity of mitochondria as the role of cyclin D1 within these processes was unknown for colorectal cancers until now. Fluorescence microscopic images showed a wide and homogeneous distribution of the cell organelles in cells with knockeddown $C C N D 1$, in contrast to control cells that had a perinuclear distribution of mitochondria (Figure 3). In addition the mitochondrial mass was increased after CCND1 knock-down. Furthermore, we could show that the high expression of CCND1 in SW480 cells contributes to reduced total cellular ATP levels.

Our results show that cyclin D1 is involved in the extent of mitochondrial distribution and the reduction of the mitochondrial mass which correlated with the mitochon- 
drial activity in the tested colon carcinoma cell line. These results are in agreement with the results of others obtained from other cell types. Sakamaki et al. have shown that cyclin D1 has an influence on the function and also on the size of mitochondria in breast cancer cells. They conclude that cyclin D1 promotes the glycolytic phenotype of mitochondria [29]. In addition, Tchakarska et al. described that cyclin D1 inhibits mitochondrial activity in B cells [30]. Cyclin D1 localizes to the outer mitochondrial membrane where it binds to a voltage-dependent anion channel and decreases the supply of ADP, ATP and metabolites, thereby reducing mitochondrial metabolism [30]. Cyclin D1 also controls glucose metabolism in hepatic cells by down-regulating PGC1 $\alpha$, thus suppressing gluconeogenesis and promoting the Warburg effect [31] [32]. Therefore, the high expression of cyclin D1 in colorectal cancer cells due to an active Wnt pathway might contribute to an altered cancer cell metabolism. After CCND1 knock-down in SW480 cells we observed that the perinuclear distribution of mitochondria was abrogated. This indicates that cyclin D1 might support perinuclear clustering of mitochondria in colorectal cancer. Similar effects were reported for factors of the tumor necrosis factor family that are able to induce clusters of mitochondria around the nucleus [33]. Clustering of mitochondria in the perinuclear region is also triggered by hypoxia in endothelial cells which show under normoxia a homogenous cytoplasmic distribution of mitochondria [34]. Al-Mehdi et al. further showed that this results in higher nuclear ROS (reactive oxygen species) levels that are responsible for hypoxia-induced upregulation of vascular endothelial growth factor (VEGF). Thus, there are several examples in the literature, where the perinuclear localization of mitochondria is linked to cell death or stress. This connection does presumably not reflect the situation in the analyzed colorectal cancer cell line SW480 which loses its perinuclear clustering of mitochondria upon $C C N D 1$ knock-down in parallel to the observed G1 arrest. Eventually, the finding that perinuclear distribution of mitochondria also correlates with pluripotency in stem cells [35] [36] enables the hypothesis that knock-down of CCND1 rather reduces the pluripotent character of SW 480 cells.

Thus, our data show that the Wnt target gene CCND1 might be involved in three main effects which are performed by the Wnt pathway in colorectal cancer cells: it is not only crucial for G1/S transition during cell cycle progression, it also alters energy metabolism and it might affect the pluripotent character. Future investigations have to show, to which extent cyclin D1 fulfils these actions in colorectal carcinoma cells in general.

\section{Acknowledgements}

This work was supported by the Bundesministerium für Bildung und Forschung [FKZ 03FH032PX3].

\section{References}

[1] Giles, R.H., van Es, J.H. and Clevers, H. (2003) Caught up in a Wnt Storm: Wnt Signaling in Cancer. Biochimica et Biophysica Acta, 1653, 1-24. 
https://doi.org/10.1016/s0304-419x(03)00005-2

[2] Wend, P., Holland, J.D., Ziebold, U. and Birchmeier, W. (2010) Wnt Signaling in Stem and Cancer Stem Cells. Seminars in Cell \& Developmental Biology, 21, 855-863. https://doi.org/10.1016/j.semcdb.2010.09.004

[3] Clevers, H. (2006) Wnt/Beta-Catenin Signaling in Development and Disease. Cell, 127, 469480. https://doi.org/10.1016/j.cell.2006.10.018

[4] Vlad, A., Röhrs, S., Klein-Hitpass, L. and Müller, O. (2008) The First Five Years of the Wnt Targetome. Cell Signal, 20, 795-802. https://doi.org/10.1016/j.cellsig.2007.10.031

[5] http://www.stanford.edu/group/nusselab/cgi-bin/wnt/

[6] Tetsu, O. and McCormick, F. (1999) Beta-Catenin Regulates Expression of Cyclin D1 in Colon Carcinoma Cells. Nature, 398, 422-426. https://doi.org/10.1038/18884

[7] Shtutman, M., Zhurinsky, J., Simcha, I., Albanese, C., D’Amico, M., Pestell, R. and Ben, Ze'ev A. (1999) The Cyclin D1 Gene Is a Target of the Beta-Catenin/LEF-1 Pathway. Proceedings of the National Academy of Sciences of the United States of America, 96. 55225527. https://doi.org/10.1073/pnas.96.10.5522

[8] Willert, J., Epping, M., Pollack, J.R., Brown, P.O. and Nusse, R. (2002) A Transcriptional Response to Wnt Protein in Human Embryonic Carcinoma Cells. BMC Developmental Biology, 2, 8. https://doi.org/10.1186/1471-213X-2-8

[9] van de Wetering, M., Sancho, E., Verweij, C., de Lau, W., Oving, I., Hurlstone, A., van der Haun, K., Batlle, E., Coudreuse, D., Haramis, A.P., Tjon-Pon-Fong, M., Moerer, P., van den Born, M., Soete, G., Pals, S., Eilers, M., Medema, R. and Clevers, H. (2002) The Beta-Catenin/ TCF-4 Complex Imposes a Crypt Progenitor Phenotype on Colorectal Cancer Cells. Cell, 111, 241-250. https://doi.org/10.1016/S0092-8674(02)01014-0

[10] Sansom, O.J., Reed, K.R., Hayes, A.J., Ireland, H., Brinkmann, H., Newton, I.P., Batlle, E., Simon-Assmann, P., Clevers, H., Nathke, I.S., Clarke, A.R. and Winton, D.J. (2004) Loss of Apc in Vivo Immediately Perturbs Wnt Signaling, Differentiation, and Migration. Genes \& Development, 18, 1385-1390. https://doi.org/10.1101/gad.287404

[11] Andreu, P., Colnot, S., Godard, C., Gad, S., Chafey, P., Niwa-Kawakita, M., Laurent-Puig, P., Kahn, A., Robine, S., Perret, C. and Romagnolo, B. (2005) Crypt-Restricted Proliferation and Commitment to the Paneth Cell Lineage Following Apc Loss in the Mouse Intestine. Development, 132, 1443-1451. https://doi.org/10.1242/dev.01700

[12] Röhrs, S., Kutzner, N., Vlad, A., Grunwald, T., Ziegler, S. and Müller, O. (2009) Chronological Expression of Wnt Target Genes CCND1, Myc, Cdkn1a, Tfrc, Plf1 and Ramp3. Cell Biology International, 33, 501-508. https://doi.org/10.1016/j.cellbi.2009.01.016

[13] Morgan, D.O. (1995) Principles of CDK Regulation. Nature, 374, 131-134. https://doi.org/10.1038/374131a0

[14] Matsushime, H., Roussel, M.F. and Sherr, C.J. (1991) Novel Mammalian Cyclins (CYL Genes) Expressed during G1. Cold Spring Harbor Symposia on Quantitative Biology, 56, 69-74. https://doi.org/10.1101/SQB.1991.056.01.010

[15] Xiong, Y. and Beach, D. (1991). Population Explosion in the Cyclin Family. Current Biolo$g y, 1,362-364$. https://doi.org/10.1016/0960-9822(91)90193-Z

[16] Pestell, R.G. (2013) New Roles of Cyclin D1. American Journal of Pathology, 183, 3-9. http://dx.doi.org/10.1016/j.ajpath.2013.03.001

[17] Sethi, J.K. and Vidal Pluig, A. (2010) Wnt Signalling and the Control of Cellular Metabolism. Biochemical Journal, 427, 1-17.http://dx.doi.org/10.1042/BJ20091866

[18] Pate, K.T., Stringari, C., Sprowl-Tanio, S., Wang, K., TeSlaa, T., Hoverter, N.P., McQuade, M.M., Garner, C., Digman, M.A., Teitell, M.A., Edwards, R.A., Gratton, E. and Waterman, 
M.L. (2014) Wnt Signaling Directs a Metabolic Program of Glycolysis and Angiogenesis in Colon Cancer. EMBO Journal, 33, 1454-1473.http://dx.doi.org/10.15252/embj.201488598

[19] Munemitsu, S., Albert, I., Souza, B., Rubinfeld, B. and Polakis, P. (1995) Regulation of Intracellular Beta-Catenin Levels by the Adenomatous Polyposis Coli (APC) Tumor-Suppressor Protein. Proceedings of the National Academy of Sciences of the United States of America, 92, 3046-3050. http://dx.doi.org/10.1073/pnas.92.7.3046

[20] Yang, K., Hitomi, M. and Stacey, D.W. (2006) Variations in Cyclin D1 Levels through the Cell Cycle Determine the Proliferative Fate of a Cell. Cell Division, 1, 32. http://dx.doi.org/10.1186/1747-1028-1-32

[21] Wang, C., Li, Z., Lu, Y., Du, R., Katiyar, S., Yang, J., Fu, M., Leader, J.E., Quong, A., Novikoff, P.M. and Pestell, R.G. (2006) Cyclin D1 Repression of Nuclear Respiratory Factor 1 Integrates Nuclear DNA Synthesis and Mitochondrial Function. Proceedings of the National Academy of Sciences of the United States of America, 103, 11567-11572. http://dx.doi.org/10.1073/pnas.0603363103

[22] Alirol, E. and Martinou, J.C. (2006) Mitochondria and Cancer: Is There a Morphological Connection? Oncogene, 25, 4706-4716. http://dx.doi.org/10.1038/sj.onc.1209600

[23] Desagher, S. and Martinou, J.C. (2000) Mitochondria as the Central Control Point of Apoptosis. Trends in Cell Biology, 10, 369-377. http://dx.doi.org/10.1016/S0962-8924(00)01803-1

[24] Okamoto, K. and Shaw, J.M. (2005) Mitochondrial Morphology and Dynamics in Yeast and Multicellular Eukaryotes. Annual Review of Genetics, 39, 503-536. http://dx.doi.org/10.1146/annurev.genet.38.072902.093019

[25] Warburg, O. (1956) On Respiratory Impairment in Cancer Cells. Science, 124, 269-270.

[26] Gatenby, R.A. and Gillies, R.J. (2004) Why Do Cancers Have High Aerobic Glycolysis? Nature Reviews Cancer, 4, 891-899.http://dx.doi.org/10.1038/nrc1478

[27] Gatenby, R.A. and Gawlinski, E.T. (1996) A Reaction-Diffusion Model of Cancer Invasion. Cancer Research, 56, 5745-5753.

[28] Schornack, P.A. and Gillies, R.J. (2003) Contributions of Cell Metabolism and $\mathrm{H}^{+}$Diffusion to the Acidic pH of Tumors. Neoplasia, 5, 135-145. http://dx.doi.org/10.1016/S1476-5586(03)80005-2

[29] Sakamaki, T., Casimiro, M.C., Ju, X., Quong, A.A., Katiyar, S., Liu, M., Jiao, X., Li, A., Zhang, X., Lu, Y., Wang, C., Byers, S., Nicholson, R., Link, T., Shemluck, M., Yang, J., Fricke, S.T., Novikoff, P.M., Papanikolaou, A., Arnold, A., Albanese, C. and Pestell, R. (2006) Cyclin D1 Determines Mitochondrial Function in Vivo. Molecular and Cellular Biology, 26, 5449-5469.http://dx.doi.org/10.1128/MCB.02074-05

[30] Tchakarska, G., Roussel, M., Troussard, X. and Sola, B. (2011) Cyclin D1 Inhibits Mitochondrial Activity in B Cells. Cancer Research, 71, 1690-1699.

http://dx.doi.org/10.1158/0008-5472.CAN-10-2564

[31] Bhalla, K., Liu, W.J., Thompson, K., Anders, L., Devarakonda, S., Dewi, R., Buckley, S., Hwang, B.J., Polster, B., Dorsey, S.G., Sun, Y., Sicinski, P. and Girnun, G.D. (2014) Cyclin D1 Represses Gluconeogenesis via Inhibition of the Transcriptional Coactivator PGC1 $\alpha$. Diabetes, 63, 3266-3278. http://dx.doi.org/10.2337/db13-1283

[32] Lee, Y., Dominy, J.E., Choi, Y.J., Jurczak, M., Tolliday, N., Camporez, J.P., Chim, H., Lim, J.H., Rua,n H.B., Yang, X., Vazquez, F., Sicinski, P., Shulman, G.I. and Puigserver, P. (2014) Cyclin D1-Cdk4 Controls Glucose Metabolism Independently of Cell Cycle Progression. Nature, 510, 547-551. http://dx.doi.org/10.1038/nature13267

[33] De Vos, K., Goossens, V., Boone, E., Vercammen, D., Vancompernolle, K., Vandenabeele, 
P., Haegeman, G., Fiers, W. and Grooten, J. (1998) The 55-kDa Tumor Necrosis Factor Receptor Induces Clustering of Mitochondria through Its Membrane-Proximal Region. The Journal of Biological Chemistry, 273, 9673-9680. http://dx.doi.org/10.1074/jbc.273.16.9673

[34] Al-Mehdi, A.B., Pastukh, V.M., Swiger, B.M., Reed, D.J., Patel, M.R., Bardwell, G.C., Pastukh, V.V., Alexeyev, M.F. and Gillespie, M.N. (2012) Perinuclear Mitochondrial Clustering Creates an Oxidant-Rich Nuclear Domain Required for Hypoxia-Induced Transcription. Science Signaling, 5, ra47. http://dx.doi.org/10.1126/scisignal.2002712

[35] Bavister, B.D. (2006) The Mitochondrial Contribution to Stem Cell Biology. Reproduction, Fertility and Development, 18, 829-838. http://dx.doi.org/10.1071/RD06111

[36] Lonergan, T., Bavister, B. and Brenner, C. (2007) Mitochondria in Stem Cells. Mitochondrion, 7, 289-296. http://dx.doi.org/10.1016/j.mito.2007.05.002

\section{Submit or recommend next manuscript to SCIRP and we will provide best service} for you:

Accepting pre-submission inquiries through Email, Facebook, LinkedIn, Twitter, etc. A wide selection of journals (inclusive of 9 subjects, more than 200 journals)

Providing 24-hour high-quality service

User-friendly online submission system

Fair and swift peer-review system

Efficient typesetting and proofreading procedure

Display of the result of downloads and visits, as well as the number of cited articles

Maximum dissemination of your research work

Submit your manuscript at: http://papersubmission.scirp.org/

Or contact jbm@scirp.org 